\title{
ВИЗНАЧЕННЯ ЕФЕКТИВНОСТІ ВПРОВАДЖЕННЯ СИСТЕМ СОНЯЧНОГО ГАРЯЧОГО ВОДОПОСТАЧАННЯ
}

\author{
С.В. Матях, канд. техн. наук, Т.В. Суржик, канд. техн. наук, В.Ф. Рєзцов, чл.-кор. НАН України, докт. техн. наук, \\ Інститут відновлюваної енергетики НАН України, \\ 02094, вул. Гната Хоткевича, 20А, м. Київ, Україна.
}

Використання сучасних сонячних колекторів забезпечує високий рівень освоєння енергії сонячного випромінювання та стабільність гарячого водопостачання на протязі всього року на всій території Украӥни. На сучасному етапі розвитку сонячної теплоенергетики на перше місие виходять проблеми ефективного використання енергї сонячної радіації за рахунок застосування передових технологій та встановлення оптимальних параметрів енергетичного обладнання.

Представлений в роботі порядок визначення ефективності використання систем сонячного гарячого водопостачання забезпечує отримання енергетичних та економічних параметрів сонячного теплоенергетичного обладнання у конкретній місиевості, визначення типу і параметрів геліоустановок для їх максимально ефективного застосування.

Вибір типу та продуктивності сонячних колекторів для певної місиевості в периу чергу орієнтовано на потреби конкретного споживача та питомі показники з надходження сонячної радіації в даній місцевості (середньомісячна $і$ середньорічна кількість прямої, розсіяної та сумарної сонячної радіаџіï). На основі представлених даних визначається приведена добова інтенсивність поглинання сонячним колектором сонячної радіації із врахуванням робочих параметрів геліотехнічної установки та оптимального кута нахилу до горизонту. Розрахункові енергетичні параметри надалі використовуються для встановлення економічної ефективності, строку окупності геліоустановки та екологічної ефективності за рахунок зменшення викидів вуглекислого газу. Сонячне теплопостачання в Україні має достатній досвід використання $і$ розвинену нормативну базу для проектування, а технологічний потенціал промисловості дозволяє вирішити завдання масового виробництва геліотехнічного обладнання. Запропонований порядок оперативного встановлення ефективності впровадження систем сонячного гарячого водопостачання для потениійних споживачів сприятиме широкому освоєнню сонячної теплової енергї на всій території України і, відповідно, зменшенню обсягів використання органічного палива та поліпшенню стану оточуючого середовища. Бібл. 7, табл. 2.

Ключові слова: сонячна теплоенергетика, сонячний колектор, гаряче водопостачання.

\section{DETERMINATION OF THE EFFICIENCY OF SOLAR HOT WATER SYSTEMS IMPLEMENTATION} S. Matyakh, candidate of technical science, T. Surzhyk, candidate of technical science, V. Ryeztsov, corresponding member of the
NAS of Ukraine, doctor of technical science

Institute of Renewable Energy NAS of Ukraine,

02094, 20A Hnata Khotkevycha St., Kyiv, Ukraine.

The use of modern solar collectors ensures a high level of utilization of solar radiation energy and the stability of hot water supply throughout the year throughout Ukraine. At the present stage of development of solar thermal power engineering, the problems of efficient use of energy of solar radiation come to the first place due to the use of advanced technologies and establishment of optimal parameters of power equipment.

The procedure for determining the efficiency of using solar hot water systems presented in the paper provides obtaining energy and economic parameters of solar thermal power equipment in a particular locality, determining the type and parameters of solar installations for their maximum effective use.

The choice of type and performance of solar collectors for a particular area is primarily focused on the needs of a particular consumer and specific indicators of solar radiation in the area (monthly and annual average amount of direct, scattered and total solar radiation). Based on the presented data, the daily absorption intensity of the solar collector of solar radiation is determined, taking into account the operating parameters of the solar engineering installation and the optimal angle of inclination to the horizon. The estimated energy parameters are further used to establish cost-effectiveness, payback time and environmental performance by reducing carbon dioxide emissions. Solar heat supply in Ukraine has sufficient experience in the use and development of a normative base for design, and the technological potential of the industry allows to write out the tasks of mass production of heliotechnical equipment. The proposed procedure for prompt establishment of the efficiency of the introduction of solar hot water systems for potential consumers will contribute to the widespread utilization of solar thermal energy throughout Ukraine and, consequently, to reducing the use of organic fuel and improving the state of the environment. Ref. 7, tabl. 2.

Keywords: solar thermal power, solar collector, hot water supply. 


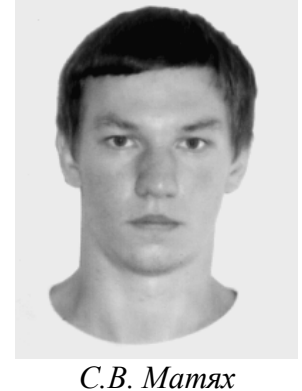

S. Matyakh

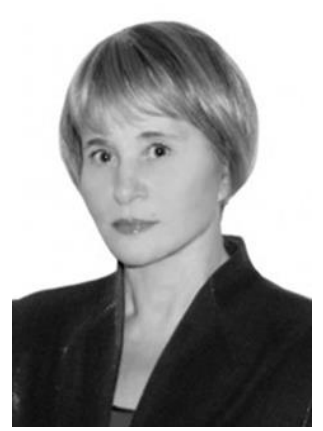

T.В. Суржик T. Surzhyk

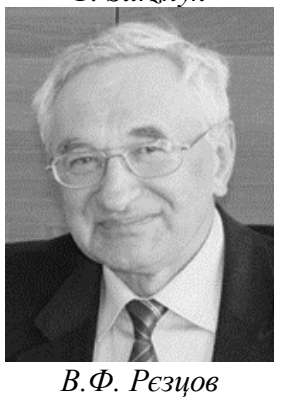

B.Ф. Рєзиов

V. Rieztsov
Відомості про автора: старший науковий співробітник в Інституті відновлюваної енергетики НАН України.

Освіта: Національний технічний університет України. «Київський політехнічний інститут ім. Ігоря Сікорського», спеціальність - Програмне забезпечення автоматизованих систем.

Наукова сфера: сонячна енергетика, моделювання енергетичних процесів.

Публікації: 31.

ORCID: 0000-0002-1707-3519

Contacts: +38 (044) 206-28-09

e-mail: renewable@ukr.net

Відомості про автора: кандидат технічних наук, вчений секретар Інституту відновлюваної енергетики НАН України.

Освіта: Київський інженерно-будівельний інсти-тут, спеціальність - теплогазопостачання та вентиляція.

Наукова сфера: відновлювана енергетика.

Публікації: 187. 2 монографії, 26 патентів.

ORCID: 0000-0002-1418-7748

Контакти: +38 (044) 206-28-09

e-mail: renewable@ukr.net

Відомості про автора: чл.-кор. НАН України, докт. техн. наук, професор, заступник директора $з$ наукових питань, завідувач відділу сонячної енергетики в Інституті відновлюваної енергетики НАН України.

Освіта: Харківський авіаційний інститут, факультет двигунів літальних апаратів, спеціальність - інженер-механік.

Наукова сфера: відновлювана енергетика.

Публікації: 308. 5 монографій, 20 патентів.

ORCID: 0000-0003-2926-1733

Contacts: +38 (044) 206-28-09

e-mail: renewable@ukr.net
Autor information: senior researcher Institite or Renewable energy of NAS of Ukraine.

Education: National Technical University of Ukraine «Igor Sikorsky Kyiv Polytechnic Institute», specialty - automated systems software.

Research area: solar power engineering, simulation of energy-intensive processes.

Publications: 31 .

ORCID: 0000-0002-1707-3519

Contacts: +38 (044) 206-28-09

e-mail: renewable@ukr.net

Autor information: Kandidate of science, Science secretary in the Institute of Renewable Energy of the National Academy the Sciences of Ukraine

Education: Kyivs Engineering Building - Institute, specialty - gas-heating and ventilation

Research area: renewable energy.

Publications: 187. 2 monographs, 26 patents.

ORCID: 0000-0002-1418-7748

Contacts: +38 (044) 206-28-09

e-mail: renewable@ukr.net

Autor information: Corresponding Member of NAS of Ukraine, DoctorTechnical Sciences, Professor, Deputy Director of Research, The Head of Department Solar Energy Institute of Renewable Energy of the National Academy the Sciences of Ukraine.

Education: Kharkiv Aviation Institute, Faculty of Aircraft Engine Engines, specialty - mechanical engineer.

Research area: renewable energy.

Publications: 308. 5 monographs, 20 patents.

ORCID: 0000-0003-2926-1733

Contacts: +38 (044) 206-28-09

e-mail: renewable@ukr.net
Вступ. 3 усіх відновлюваних джерел сонячна енергія $\epsilon$ найбільш доступним природним енергоресурсом і в контексті їі використання накопичено багатовіковий історичний досвід. Переваги практично невичерпного джерела енергії сонячної радіації як первинного місцевого енергоресурсу полягають у можливості використання на більшості ділянок поверхні Землі та в можливості безпосереднього перетворення енергії сонячної радіації в теплову та електричну енергію.

Сонячна теплова енергетика - один із перспективних напрямів використання енергії Сонця на території України. На сучасному етапі іiі розвитку на перше місце виходять проблеми ефективного використання енергії сонячної радіації за рахунок застосування передових технологій та встановлення оптимальних параметрів енергетичного обладнання. Сучасні сонячні колектори забезпечують високий рівень освоєння енергії сонячного випромінювання та стабільність гарячого водопостачання на протязі всього року.
Постановка задачі. Для підвищення рівня впровадження систем сонячного гарячого водопостачання запропоновано алгоритм визначення ефективності їх використання, який забезпечує отримання енергетичних та економічних параметрів сонячного теплоенергетичного обладнання у конкретній місцевості, визначення типу і параметрів геліоустановок для їх максимально ефективного використання.

Основними параметрами, що використовуються при визначенні ефективності впровадження сонячних теплових енергоустановок $є$ інтенсивність надходження сонячної радіації і температура зовнішнього повітря.

Сумарне сонячне випромінювання, що поступає на любу поверхню, складається 3 прямої $\mathrm{i}$ розсіяної сонячної радіації та випромінювання, що відбивається від поверхні Землі і різних предметів, розташованих поблизу цієї поверхні.

Величина енергії сонячної радіації в значній мірі залежить від астрономічних та метеорологі- 
чних факторів - висоти Сонця над горизонтом тривалості дня, хмарності, вологості та прозорості атмосфери.

Надходження сумарної сонячної радіації змінюється на протязі дня, року та з року в рік, однак середньорічні iї значення за багаторічний період достатньо стійкі.

Крім того, змінними величинами $\epsilon$ самі складові сумарної сонячної радіації (пряма та розсіяна сонячна радіація), причому часто збільшення однієї з величин приводить до зменшення іншої, майже не впливаючи на їх суму. Складова прямої сонячної радіації в добовій сумі сонячної радіації, що попадає на горизонтальну поверхню Землі, може знаходитись в діапазоні від 90\% в дуже ясний день і до $0 \%$ в дуже хмарний день. Величина сумарної сонячної радіації із збільшенням висоти місцевості до 200 м практично не змінюється - в даному випадку змінюється співвідношення іiї складових - збільшення величини прямої сонячної радіації компенсується зменшенням величини розсіяної сонячної радіації. Як правило, найбільшу долю в сумарній сонячній радіації складає пряма радіація (за виключенням зимових місяців i окремих районів, наприклад, північних) [1, 2].

Величина та співвідношення складових сумарної сонячної радіації необхідні для вибору типу геліоенергетичного обладнання. В регіонах, де переважає пряма сонячна радіація, можна застосовувати сонячні колектори 3 концентраторами сонячного випромінювання. Розсіяне сонячне випромінювання не можна сконцентрувати за допомогою дзеркал. Якщо значна частина сонячної радіації поступає у вигляді розсіяної, тоді використовують плоскі сонячні колектори, які збирають як пряме, так і розсіяне сонячне випромінювання і можуть ефективно застосовуватись не тільки в ясні, але й в хмарні дні.

При виборі типу та потужності сонячної теплової енергоустановки для певної місцевості в першу чергу необхідно орієнтуватись на питомі показники 3 надходження сонячної радіації в даній місцевості (середньомісячна і середньорічна кількість прямої, розсіяної та сумарної сонячної радіації), продуктивність геліотехнічної установки [1 - 4].

Розрахункові питомі енергетичні показники надходження сонячної енергії на горизонтальну поверхню в різних регіонах України визначені за даними щодо надходження сонячної радіації на діючих в Україні метеостанціях - прямої сонячної радіації, розсіяної сонячної радіації та сумарної сонячної радіації представлено в таблиці $1[5,6]$.

Таблиця 1. Надходження сонячної енергії на горизонтальну поверхню в регіонах України: S - прямої сонячної радіації, D - розсіяної сонячної радіації, $(\mathrm{S}+\mathrm{D})$ - сумарна радіація.

Table 1. Solar energy supply to the horizontal surface in the regions of Ukraine: $\mathrm{S}$ - direct solar radiation, D - diffuse solar radiation, $(\mathrm{S}+\mathrm{D})$ - total radiation.

\begin{tabular}{|c|c|c|c|c|c|c|c|c|c|c|c|c|c|c|}
\hline Обл: & $\begin{array}{c}\text { Радіа- } \\
\text { ція, } \\
\text { кВт.год/ } / \mathbf{M}^{2}\end{array}$ & I & II & III & IV & V & VI & VII & VIII & IX & $\mathbf{X}$ & XI & XII & Рік \\
\hline 1 & 2 & 3 & 4 & 5 & 6 & 7 & 8 & 9 & 10 & 11 & 12 & 13 & 14 & 15 \\
\hline \multirow{3}{*}{$\begin{array}{l}\text { 1. Чернігівська } \\
\text { (Придеснянська МТС) }\end{array}$} & $S$ & 4,656 & 10,475 & 27,94 & 48,89 & 77,99 & 83,81 & 4,97 & 73,33 & 45,40 & 24,44 & 8,148 & 4,656 & 494,7 \\
\hline & $\mathrm{D}$ & 20,95 & 31,43 & 51,22 & 59,36 & 81,48 & 76,82 & 83,81 & 67,51 & 48,89 & 32,59 & 13,97 & 10,476 & 578,5 \\
\hline & $\mathrm{S}+\mathrm{D}$ & 25,61 & \begin{tabular}{|l|}
41,91 \\
\end{tabular} & 79,16 & 108,25 & 159,47 & 160,63 & 168,78 & 140,84 & 94,29 & 57,03 & 22,12 & 15,13 & 1073,2 \\
\hline \multirow{3}{*}{$\begin{array}{l}\text { 2. Сумська } \\
\text { (КонотопськаМТС) }\end{array}$} & $\mathrm{S}$ & 4,656 & 13,97 & 36,08 & 47,72 & 74,5 & 84,97 & 91,96 & 74,5 & 51,22 & 20,95 & 6,94 & 3,49 & 511 \\
\hline & $\mathrm{D}$ & 19,79 & 27,94 & 47,72 & 62,86 & 82,64 & 81,48 & 82,64 & 68,68 & 48,89 & 31,43 & 15,13 & 12,8 & 582 \\
\hline & $\mathrm{S}+\mathrm{D}$ & 24,45 & 41,91 & 83,80 & 110,58 & 157,14 & 166,45 & 174,6 & 143,18 & 100,11 & 52,38 & 22,07 & 16,29 & 1093 \\
\hline \multirow{3}{*}{$\begin{array}{l}\text { 3. Волинська } \\
\text { (Ковельська МТС) }\end{array}$} & $\mathrm{S}$ & 4,656 & 11,64 & 38,41 & 46,56 & 69,84 & 84,97 & 74,5 & 60,53 & 45,4 & 20,95 & 6,98 & 4,656 & \begin{tabular}{|l|}
469,02 \\
\end{tabular} \\
\hline & $\mathrm{D}$ & 20,95 & 31,43 & 52,38 & 64,02 & 83,81 & 84,97 & 84,97 & 72,17 & 52,38 & 34,92 & 15,13 & 12,8 & 609,94 \\
\hline & $\mathrm{S}+\mathrm{D}$ & 25,61 & 43,07 & 90,79 & 110,58 & 153,65 & 169,94 & 159,47 & 132,7 & \begin{tabular}{|l|}
97,78 \\
\end{tabular} & 55,87 & 22,11 & 17,46 & \begin{tabular}{|l|}
1078,96 \\
\end{tabular} \\
\hline \multirow{3}{*}{$\begin{array}{l}\text { 4. Київська } \\
\text { (Тетерівська МТС) }\end{array}$} & $\mathrm{S}$ & 4,656 & 11,64 & 33,76 & 48,89 & 73,33 & 86,14 & 87,3 & 71,0 & 45,4 & 24,44 & 5,82 & 3,49 & \begin{tabular}{|l|}
495,86 \\
\end{tabular} \\
\hline & $\mathrm{D}$ & 22,12 & 29,1 & 46,56 & 68,68 & 75,66 & 80,32 & 80,32 & 62,86 & 50,05 & 32,6 & 16,3 & 10,48 & 575,02 \\
\hline & $\mathrm{S}+\mathrm{D}$ & 26,78 & 40,74 & 80,32 & 117,57 & 148,99 & 166,46 & 167,62 & 133,86 & 95,45 & 57,04 & 22,12 & 13,97 & 1070,88 \\
\hline \multirow{3}{*}{$\begin{array}{l}\text { 5. Киӥвська } \\
\text { (МТС м. Києва) }\end{array}$} & $\mathrm{S}$ & 6,98 & \begin{tabular}{|l|}
15,13 \\
\end{tabular} & 36,08 & 53,54 & 82,64 & 98,94 & 95,45 & 82,64 & 57,04 & 29,1 & 6,98 & 4,66 & 569,2 \\
\hline & $\mathrm{D}$ & 19,79 & \begin{tabular}{|l|}
26,77 \\
\end{tabular} & 47,72 & 62,86 & 79,15 & 83,81 & 81,48 & 66,35 & 48,89 & 33,76 & 17,46 & 13,97 & 582 \\
\hline & $5+\mathrm{D}$ & 26,77 & 41,9 & 83,8 & 116,4 & 161,8 & 182,75 & 176,93 & 149,0 & 105,93 & 62,86 & 24,44 & 18,63 & \begin{tabular}{|l|}
1151,2 \\
\end{tabular} \\
\hline \multirow{3}{*}{$\begin{array}{l}\text { 6. Київська } \\
\text { (Баришівська МТС) }\end{array}$} & $S$ & 8,15 & \begin{tabular}{|l|}
13,97 \\
\end{tabular} & 30,26 & 54,71 & 79,15 & 94,28 & 97,78 & 79,15 & 52,38 & 27,94 & 8,15 & 3,49 & \begin{tabular}{|l|}
549,41 \\
\end{tabular} \\
\hline & $\mathrm{D}$ & 19,79 & 26,77 & 41,9 & 65,18 & 76,82 & 83,81 & 81,48 & 66,35 & 48,89 & 31,45 & 17,46 & 11,64 & \begin{tabular}{|l|}
571,52 \\
\end{tabular} \\
\hline & $\mathrm{S}+\mathrm{D}$ & 27,94 & \begin{tabular}{|l|}
40,74 \\
\end{tabular} & 72,16 & 119,89 & 155,97 & 178,09 & 179,26 & 145,5 & 101,27 & 59,37 & 25,61 & 15,13 & \begin{tabular}{|l|}
1120,93 \\
\end{tabular} \\
\hline \multirow{3}{*}{$\begin{array}{l}\text { 7. Київська } \\
\text { (Бориспільська МТС) }\end{array}$} & $S$ & 6,98 & 13,97 & 29,1 & 53,54 & 87,3 & 91,96 & 97,78 & 76,82 & 52,38 & 29,1 & 6,98 & 3,49 & 549,41 \\
\hline & $\mathrm{D}$ & 20,95 & 29,1 & 43,07 & 66,35 & 80,32 & 83,81 & \begin{tabular}{|l|}
79,15 \\
\end{tabular} & 66,35 & 50,05 & 31,43 & 17,46 & 12,8 & 580,84 \\
\hline & $\mathrm{S}+\mathrm{D}$ & 27,93 & \begin{tabular}{|l|}
43,07 \\
\end{tabular} & 72,17 & 119,89 & 167,62 & 175,77 & 176,93 & 143,17 & 102,43 & 60,53 & 24,44 & 16,29 & 1130,24 \\
\hline
\end{tabular}




\begin{tabular}{|c|c|c|c|c|c|c|c|c|c|c|c|c|c|c|}
\hline Область & \begin{tabular}{|c|} 
Радіа- \\
ція, \\
кВт.год/м²
\end{tabular} & I & II & III & IV & V & VI & VII & VIII & IX & $\mathbf{X}$ & XI & XII & Рік \\
\hline 1 & 2 & 3 & 4 & 5 & 6 & 7 & 8 & 9 & 10 & 11 & 12 & 13 & 14 & 15 \\
\hline \multirow{3}{*}{$\begin{array}{l}\text { 8. Хмельницька } \\
\text { (Нова Ушиця МТС) }\end{array}$} & $S$ & 8,15 & 16,3 & 38,41 & 54,71 & 72,17 & 88,46 & 94,28 & 80,32 & 60,53 & 31,43 & 8,15 & 6,98 & 559,88 \\
\hline & $\mathrm{D}$ & 24,44 & 33,76 & 54,71 & 66,35 & 84,97 & 83,81 & 83,81 & 67,51 & 48,89 & 33,76 & 18,62 & 16,3 & 616,92 \\
\hline & $\mathrm{S}+\mathrm{D}$ & \begin{tabular}{|l|}
32,59 \\
\end{tabular} & 50,06 & 93,12 & 121,06 & 157,14 & 172,27 & 178,09 & 147,83 & 109,42 & \begin{tabular}{|l|}
65,19 \\
\end{tabular} & 26,77 & 23,28 & 1176,8 \\
\hline \multirow{3}{*}{$\begin{array}{l}\text { 9. Луганська } \\
\text { (Деркульська МТС) }\end{array}$} & $\mathrm{S}$ & 9,31 & 19,79 & 50,05 & 74,5 & 98,94 & 130,37 & 116,4 & 107,09 & \begin{tabular}{|l|}
73,33 \\
\end{tabular} & 25,61 & 11,64 & 4,66 & 721,7 \\
\hline & $\mathrm{D}$ & 20,95 & 31,43 & 52,38 & 55,87 & 68,68 & 71,0 & 73,33 & 61,69 & 45,4 & 33,76 & 20,95 & 15,13 & 550,57 \\
\hline & $\mathrm{S}+\mathrm{D}$ & 30,26 & 51,22 & 102,43 & 130,37 & 167,62 & 201,37 & 189,73 & 168,78 & 118,73 & 59,37 & 32,59 & 19,79 & 1272,25 \\
\hline \multirow{3}{*}{ 10. Кропивницька } & $\mathrm{S}$ & 8,15 & 17,46 & 36,08 & 60,53 & 77,99 & 98,94 & 102,43 & 89,63 & 69,84 & 34,92 & 9,31 & 4,66 & 609,94 \\
\hline & $\mathrm{D}$ & 19,79 & 29,1 & 48,89 & 55,87 & 82,64 & 77,99 & 82,64 & 61,69 & 40,74 & 30,26 & 16,3 & 16,3 & 562,2 \\
\hline & $\mathrm{S}+\mathrm{D}$ & 27,94 & 46,56 & 84,97 & 116,4 & 160,63 & 176,93 & 185,07 & 151,32 & 110,58 & 65,18 & 25,61 & 20,96 & 1172,15 \\
\hline \multirow{3}{*}{$\begin{array}{l}\text { 11. Донецька, (Вели- } \\
\text { ко-Анадольська МТС) }\end{array}$} & $\mathrm{S}$ & 8,15 & 17,46 & 39,58 & 60,53 & 88,47 & 108,25 & 116,4 & 104,76 & \begin{tabular}{|l|}
73,33 \\
\end{tabular} & 37,25 & 10,45 & 3,49 & 668,14 \\
\hline & $\mathrm{D}$ & 22,12 & 31,43 & 54,71 & 60,53 & 79,15 & 74,5 & 74,5 & 61,7 & 44,23 & 33,76 & 20,95 & 18,62 & 576,2 \\
\hline & $\mathrm{S}+\mathrm{D}$ & 30,27 & 48,89 & 94,29 & 121,06 & 167,62 & 182,75 & 190,9 & 166,46 & 117,56 & \begin{tabular}{|l|}
71,01 \\
\end{tabular} & 31,40 & 22,11 & 1244,34 \\
\hline \multirow{3}{*}{ 12. Закарпатська } & $\mathrm{S}$ & 9,31 & 15,13 & 44,23 & 62,86 & 82,64 & 91,96 & 90,79 & 87,3 & 71,0 & 39,58 & 10,48 & 6,98 & 612,26 \\
\hline & $\mathrm{D}$ & 20,95 & 30,26 & 48,89 & 62,86 & 82,64 & 82,64 & 84,97 & 71,0 & 50,05 & 34,92 & 20,95 & 11,64 & 601,8 \\
\hline & $\mathrm{S}+\mathrm{D}$ & 30,26 & 45,39 & 93,12 & 125,72 & 165,28 & 174,6 & 175,76 & 158,3 & 121,05 & \begin{tabular}{|l|}
74,5 \\
\end{tabular} & 31,43 & 18,62 & 4,05 \\
\hline \multirow{3}{*}{$\begin{array}{l}\text { 13. Одеська } \\
\text { (МТС м. Одеса) }\end{array}$} & $\mathrm{S}$ & 9,31 & 16,3 & 43,07 & 76,82 & 114,07 & 130,37 & 143,17 & 121,06 & 84,97 & 39,58 & 12,8 & 8,15 & 799,67 \\
\hline & $\mathrm{D}$ & 23,28 & 30,26 & 51,22 & 64,02 & 73,33 & 71,0 & 67,51 & 57,04 & 45,4 & 39,58 & 22,12 & 19,79 & 564,55 \\
\hline & $\mathrm{S}+\mathrm{D}$ & \begin{tabular}{|l|}
32,59 \\
\end{tabular} & 46,56 & 94,29 & 140,84 & 187,4 & 201,37 & 210,68 & 178,10 & 130,37 & \begin{tabular}{|l|}
79,16 \\
\end{tabular} & 34,92 & 27,94 & 1364,2 \\
\hline \multirow{3}{*}{$\begin{array}{l}\text { 14. Одеська } \\
\text { (Болградська МТС) }\end{array}$} & $\mathrm{S}$ & 15,13 & 20,95 & 44,23 & 59,36 & 88,46 & 100,1 & 121,06 & 111,74 & 86,14 & 46,56 & 13,97 & 10,48 & 718,2 \\
\hline & $\mathrm{D}$ & 22,12 & 29,1 & 47,72 & 59,36 & 72,17 & 69,84 & 68,68 & 61,69 & 44,23 & 36,08 & 20,95 & 17,46 & 549,4 \\
\hline & $\mathrm{S}+\mathrm{D}$ & \begin{tabular}{|l|}
37,25 \\
\end{tabular} & 50,05 & 91,95 & 118,72 & 160,63 & 169,94 & 189,74 & 173,43 & 130,37 & 82,64 & 34,92 & 27,94 & 1267,6 \\
\hline \multirow{3}{*}{15 Полтавська } & $S$ & 8,15 & 16,3 & 32,59 & 50,05 & 80,32 & 97,78 & \begin{tabular}{|c|}
97,78 \\
\end{tabular} & 84,97 & 55,87 & \begin{tabular}{|l|}
23,28 \\
\end{tabular} & 10,48 & 4,66 & 562,2 \\
\hline & $\mathrm{D}$ & 18,62 & 26,77 & 47,72 & 68,68 & 73,33 & 74,5 & 79,15 & 57,04 & \begin{tabular}{|l|}
48,89 \\
\end{tabular} & 31,43 & 15,13 & 13,97 & 544,75 \\
\hline & $\mathrm{S}+\mathrm{D}$ & 26,77 & 43,07 & 80,32 & 118,73 & 153,65 & 172,3 & 176,93 & 142,01 & 104,76 & 54,71 & 25,61 & 18,63 & 1106,95 \\
\hline \multirow{3}{*}{$\begin{array}{l}\text { 16. Запорізька } \\
\text { (Ботєвська МТС) }\end{array}$} & $\mathrm{S}$ & 6,98 & 17,46 & 37,23 & 64,02 & 100,1 & 111,74 & 123,38 & 105,92 & \begin{tabular}{|l|}
77,99 \\
\end{tabular} & 34,92 & 11,64 & 4,66 & 696,07 \\
\hline & D & \begin{tabular}{|l|}
22,12 \\
\end{tabular} & 32,59 & 51,22 & 67,51 & 75,66 & 75,66 & 76,82 & 62,86 & 46,56 & \begin{tabular}{|l|}
37,25 \\
\end{tabular} & 20,95 & 16,3 & 585,49 \\
\hline & $\mathrm{S}+\mathrm{D}$ & 29,1 & 50,05 & 88,45 & 131,53 & 175,76 & 187,4 & 200,2 & 168,78 & 124,55 & \begin{tabular}{|l|}
72,17 \\
\end{tabular} & 32,59 & 20,96 & 1281,56 \\
\hline \multirow{3}{*}{$\begin{array}{l}\text { 17. Херсонська } \\
\text { (Асканія-Нова МТС) }\end{array}$} & $S$ & 11,64 & 18,62 & 44,23 & 67,51 & 104,76 & 118,73 & 132,7 & 112,91 & 80,32 & 43,07 & 15,13 & 8,15 & 757,76 \\
\hline & $\mathrm{D}$ & 23,28 & 33,76 & 51,22 & 67,51 & 80,32 & 77,99 & 71,0 & 64,02 & \begin{tabular}{|l|}
48,89 \\
\end{tabular} & 33,76 & 20,95 & 17,46 & 590,15 \\
\hline & $\mathrm{S}+\mathrm{D}$ & \begin{tabular}{|l|}
34,92 \\
\end{tabular} & 52,38 & 95,45 & 135,02 & 185,08 & 196,72 & 203,7 & 176,93 & 129,21 & \begin{tabular}{|l}
76,83 \\
\end{tabular} & 36,08 & 25,61 & 1347,91 \\
\hline \multirow{3}{*}{$\mid \begin{array}{l}\text { 18. Херсонська } \\
\text { (МТС м. Херсон) }\end{array}$} & $\mathrm{S}$ & 10,48 & 18,62 & 43,07 & 66,36 & 102,43 & 118,73 & 125,71 & 115,24 & \begin{tabular}{|l|}
76,82 \\
\end{tabular} & 39,58 & \begin{tabular}{|l|}
12,8 \\
\end{tabular} & 9,31 & 739,14 \\
\hline & $\mathrm{D}$ & 20,95 & 31,43 & 54,71 & 65,18 & 79,15 & 76,82 & \begin{tabular}{|l|}
77,99 \\
\end{tabular} & 62,86 & 50,05 & 38,41 & 22,12 & 17,46 & 597,13 \\
\hline & $\mathrm{S}+\mathrm{D}$ & \begin{tabular}{|l|}
31,43 \\
\end{tabular} & 50,05 & 97,78 & 131,53 & 181,58 & 195,55 & 203,7 & 178,10 & 126,87 & \begin{tabular}{|l|}
77,99 \\
\end{tabular} & 34,92 & 26,77 & 1336,27 \\
\hline \multirow{3}{*}{$\begin{array}{l}\text { 19. АР Крим } \\
\text { (Свпаторійська МТС) }\end{array}$} & $\mathrm{S}$ & 15,13 & 20,95 & 47,72 & 77,99 & 96,61 & 123,38 & 145,5 & 123,38 & \begin{tabular}{|l|}
87,3 \\
\end{tabular} & \begin{tabular}{|l}
59,36 \\
\end{tabular} & 22,12 & 11,64 & 831,1 \\
\hline & $\mathrm{D}$ & \begin{tabular}{|l|}
24,44 \\
\end{tabular} & 31,43 & 51,22 & 59,36 & 73,33 & 69,84 & 66,35 & 57,04 & \begin{tabular}{|l|}
48,89 \\
\end{tabular} & \begin{tabular}{|l|}
38,41 \\
\end{tabular} & 27,94 & 20,95 & 569,2 \\
\hline & $\mathrm{S}+\mathrm{D}$ & \begin{tabular}{|l|}
39,57 \\
\end{tabular} & 52,38 & 98,94 & 137,35 & 169,94 & 193,22 & 211,85 & 180,42 & 136,19 & \begin{tabular}{|l|}
97,77 \\
\end{tabular} & 50,06 & 32,59 & 1400,3 \\
\hline \multirow{3}{*}{$\begin{array}{l}\text { 20. АР Крим } \\
\text { (Карадагська МТС) }\end{array}$} & $\mathrm{S}$ & 16,3 & 20,95 & 44,23 & 74,5 & 110,58 & 135,02 & 145,5 & 125,71 & 95,45 & \begin{tabular}{|l}
51,22 \\
\end{tabular} & 20,95 & 11,64 & 852,05 \\
\hline & D & \begin{tabular}{|l|}
27,94 \\
\end{tabular} & 34,92 & 53,54 & 65,18 & 71,0 & 66,35 & 58,2 & 45,4 & 39,58 & 39,58 & 25,61 & 20,95 & 584,34 \\
\hline & $\mathrm{S}+\mathrm{D}$ & 44,24 & 55,87 & 97,77 & 139,68 & 181,58 & 201,37 & 203,7 & 171,11 & 135,03 & \begin{tabular}{|c|}
90,8 \\
\end{tabular} & 46,56 & 32,59 & 1436,4 \\
\hline \multirow{3}{*}{$\begin{array}{l}\text { 21. АР Крим } \\
\text { (Нікітський сад МТС) }\end{array}$} & $\mathrm{S}$ & 16,3 & 22,12 & 47,72 & 73,33 & 98,94 & 117,56 & 131,53 & 122,22 & \begin{tabular}{|l|}
83,81 \\
\end{tabular} & 51,22 & 22,12 & 13,97 & 800,83 \\
\hline & $\mathrm{D}$ & 19,79 & 27,94 & 45,4 & 61,7 & 72,17 & 69,84 & 68,68 & 57,04 & 46,56 & 38,41 & 25,61 & 17,46 & 550,6 \\
\hline & $\mathrm{S}+\mathrm{D}$ & 36,09 & 50,06 & 93,12 & 135,03 & 171,11 & 187,4 & 200,21 & 179,26 & 130,37 & 89,63 & 47,73 & 31,43 & 1351,4 \\
\hline
\end{tabular}

При впровадженні сонячного колектора визначається добова потреба споживача в тепловій енергії $\left(Q_{д}\right.$, кВт год) для гарячого водопостачання (ГВП):

$$
Q_{\text {д }}=m c_{p}\left(t_{26}-t_{x в}\right),
$$

де: $\mathrm{m}$ - потреби у гарячій воді з температурою $60^{\circ} \mathrm{C}$ за добу, ${ }^{3} /$ доба; $\mathrm{c}_{\mathrm{p}}-$ питома теплоємність води, 1,16 кВТгод/( $\left.{ }^{3}{ }^{\circ} \mathrm{C}\right) ; \mathrm{t}_{\mathrm{rB}^{-}}$температура гарячої води; $\mathrm{t}_{\mathrm{xв}}-$ температура води в холодному водопроводі, яка дорівнює $5^{\circ} \mathrm{C}$ в опалювальний період та $15^{\circ} \mathrm{C}$ - в літній період.
Наступним етапом є визначення приведеної добової інтенсивності поглинання сонячної радіації $\left(\mathrm{q}_{\theta i}, \mathrm{\kappa BT}\right.$ год/ $\left.\mathrm{M}^{2}\right)$ геліоприймачем [7]:

$$
q_{\theta i}=0,96\left(P_{s} \theta_{s} I_{s}+P_{D} \theta_{D} I_{D}\right),
$$

де $\mathrm{I}_{\mathrm{S}}, \mathrm{I}_{\mathrm{D}}$ - інтенсивність сонячного випромінювання, відповідно прямого та розсіяного, на горизонтальну поверхню, кВт/м² (таблиця 1 ); $\theta_{\mathrm{S}}, \theta_{\mathrm{D}}-$ приведені оптичні характеристики для прямої $\mathrm{i}$ розсіяної сонячної радіації відповідно. При відсутності паспортних даних $\theta_{\mathrm{S}}$ приймається 0,74 , $\theta_{\mathrm{D}}=0,64$ для геліоприймача 3 одинарним склом 
$\theta_{\mathrm{S}}=0,63, \theta_{\mathrm{D}}=0,42$ для геліоприймача 3 подвійним склом; $\mathrm{P}_{\mathrm{S}}, \mathrm{P}_{\mathrm{D}}$ - коефіцієнти положення сонячного колектора для прямої і розсіяної сонячної радіації відповідно.

Середньомісячні значення коефіцієнта положення сонячного колектора для прямої сонячної радіації $\mathrm{P}_{\mathrm{S}}$ для сонячних колекторів південної орієнтації при різних кутах нахилу їх до горизонту для всіх кліматичних зон України визначають- ся 3 табличних даних (таблиця 2) [6, 7].

Розрахунковий коефіцієнт положення сонячного колектора для розсіяної сонячної радіації $\left(\mathrm{P}_{\mathrm{D}}\right)$ визначається :

$$
P_{D}=\cos ^{2} b / 2,
$$

де b - кут нахилу сонячного колектора до горизонту.

Таблиця 2. Середньомісячні значення $\mathrm{P}_{\mathrm{S}}$ для сонячних колекторів південної оріснтації.

Table 2. Monthly PS average values for southern orientation solar collectors.

\begin{tabular}{|c|c|c|c|c|c|c|c|c|c|c|c|c|}
\hline \multirow{3}{*}{$\begin{array}{c}\text { Кут нахилу ко- } \\
\text { лектору до } \\
\text { гори- } \\
\text { зонту (b), град. }\end{array}$} & \multicolumn{12}{|c|}{ Місяці року } \\
\hline & I & II & II & IV & $\mathbf{V}$ & VI & VII & VIII & IX & $\mathbf{X}$ & XI1 & XII \\
\hline & \multicolumn{12}{|c|}{ Широта місцевості $40^{\circ}$} \\
\hline 25 & 1,76 & 1,49 & 1,30 & 1,13 & 1,04 & 1,0 & 1,01 & 1,08 & 1,22 & 1,4 & 1,66 & 1,85 \\
\hline 40 & 2,24 & 1,72 & 1,36 & 1,11 & 0,97 & 0,90 & 0,93 & 1,03 & 1,24 & 1,55 & 2,03 & 2,45 \\
\hline 55 & 2,46 & 1,79 & 1,33 & 1,03 & 0,86 & 0,78 & 0,81 & 0,94 & 1,17 & 1,56 & 2,18 & 2,72 \\
\hline \multirow[t]{2}{*}{90} & 2,30 & 1,48 & 0,91 & 0 & 0 & 0 & 0 & 0 & 0,75 & 1,17 & 1,96 & 2,61 \\
\hline & \multicolumn{12}{|c|}{ Широта місцевості $45^{0}$} \\
\hline 30 & 2,14 & 1,71 & 1,42 & 1,19 & 1,07 & 1,02 & 1,04 & 1,13 & 1,30 & 1,56 & 1,96 & 2,31 \\
\hline 45 & 2,86 & 1,99 & 1,49 & 1,17 & 1,00 & 0,92 & 0,95 & 1,08 & 1,33 & 1,74 & 2,47 & 3,27 \\
\hline 60 & 3,13 & 2,07 & 1,45 & 1,09 & 0,89 & 0,80 & 0,84 & 0,99 & 1,26 & 1,76 & 2,66 & 3,64 \\
\hline \multirow[t]{2}{*}{90} & 3,04 & 1,81 & 0,99 & 0,71 & 0 & 0 & 0 & 0 & 0,89 & 1,37 & 2,5 & 3,63 \\
\hline & \multicolumn{12}{|c|}{ Широта місцевості 50 } \\
\hline 35 & 2,77 & 2,01 & 1,57 & 1,27 & 1,11 & 1,05 & 1,08 & 1,19 & 1,42 & 1,79 & 2,44 & 3,12 \\
\hline 50 & 4,06 & 2,38 & 1,65 & 1,24 & 1,04 & 0,95 & 0,98 & 1,33 & 1,44 & 2 & 3,22 & 5,27 \\
\hline 65 & 4,46 & 2,47 & 1,61 & 1,16 & 0,93 & 0,82 & 0,87 & 1,04 & 1,37 & 2,02 & 3,47 & 5,9 \\
\hline \multirow[t]{2}{*}{90} & 4,46 & 2,26 & 1,3 & 0,84 & 0 & 0 & 0 & 0,72 & 1,06 & 1,77 & 3,36 & 6,04 \\
\hline & \multicolumn{12}{|c|}{ Широта місцевості $55^{\circ}$} \\
\hline 40 & 4 & 2,47 & 1,79 & 1,37 & 1,17 & 1,09 & 1,12 & 1,26 & 1,56 & 2,11 & 3,27 & 4,91 \\
\hline 55 & 3,37 & 2,99 & 1,87 & 1,34 & 1,09 & 0,99 & 1,03 & 1,21 & 1,59 & 2,38 & 4,81 & 5,85 \\
\hline 70 & 9,29 & 3,11 & 1,83 & 1,26 & 0,98 & 0,87 & 0,91 & 1,11 & 1,51 & 2,41 & 5,2 & 6,4 \\
\hline 90 & 9,52 & 2,95 & 1,57 & 1 & 0,73 & 0 & 0 & 0,84 & 1,26 & 2,2 & 5,17 & 6,45 \\
\hline
\end{tabular}

Загальна площа абсорбера $\left(A, \mathrm{~m}^{2}\right)$ становить

$$
A=\frac{q_{\theta i}}{Q_{\text {д }} \cdot \eta}
$$

де $\mathrm{q}_{\theta i}$ - середнє значення доступної сонячної енергії, кВтггод/м²; $Q_{\text {д }}$ - значення енергії необхідної для підігріву заданого об'єму води, кВтгод; $\eta$ - середній ККД сонячної геліоустановки.

Необхідна кількість колекторів, $N_{c k}$ визначається:

$$
N_{c k}=\frac{A}{S_{a b}},
$$

де $S_{a b}$ - робоча площа одного абсорбера, м².

Строк окупності геліоустановки

$$
T=\frac{S_{C}}{Q \cdot C_{T}}
$$

де Sc -вартість геліоустановки, грн./кв.м, Q - piчна кількість теплоти, вироблена 1кв.м установки, $\mathrm{C}_{\mathrm{T}}$ - вартість теплоти від традиційного енергоджерела, грн./1 кВтгод.

Для визначення економічної ефективності розраховується сума, необхідна для оплати централізованого гарячого водопостачання за рік для

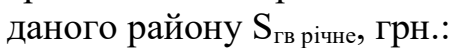

$$
\begin{gathered}
S_{\text {гв річне }}=\sum_{1}^{12} S_{26}, \\
E_{\text {екон. }}=S_{\text {затрати на ГВП }}- \\
-S_{\text {затрати на геліоустановку. }} .
\end{gathered}
$$


Екологічна ефективність, тобто заощаджена кількість викидів $\mathrm{CO}_{2}$ становить:

$$
E_{\text {еко }}=Q k,
$$

де $\kappa$ - коефіцієнт викидів $\mathrm{CO}_{2}\left(1,32\right.$ т $\mathrm{CO}_{2}$ на 1 МВт॰год).

Висновок. Використання алгоритму визначення ефективності впровадження систем сонячного гарячого водопостачання забезпечує отримання енергетичних та економічних параметрів сонячного теплоенергетичного обладнання у конкретній місцевості, визначення типу і параметрів геліоустановок для їх максимально ефективного використання. Подальша розробка програмного забезпечення на основі представленого алгоритму дасть можливість оперативного встановлення доцільності застосування сонячного теплоенергетичного обладнання на всій території України та сприятиме широкомасштабному їх впровадженню.

1. Кудря С.О. Нетрадиційні та відновлювані джерела енергії . Підручник. Національний технічний університет України («КПІ»). Київ. 2012. 495 с.

2. Мхитарян Н.M. Энергетика нетрадиционных и возобновляемых источников. Наукова думка. Київ. 1999. $314 \mathrm{c}$.

3. Даффи У.Дж., Бекман У.А. Тепловые процессы с использованием солнечной энергии. Под ред. Ю.Н.Малевского. Москва. 1977. 420 с.

4. Твайделл Дж., Уэйр А. Возобновляемые источники энергии. Энергоатомиздат. Москва. 1990. 344 с.

5. Научно-прикладной справочник по климату СССР Сер. Вып. 10. УССР. Кн. 1. Ч. 1. Солнечная радиация и солнечное сияние. Гидрометеоиздат. 1990. 608 с.

6. Рекомендации по проектированию установок солнечного горячего водоснабжения для жилых и общественных зданий. КиевЗНИИЭП. Киев. 1987. 119 с.

7. Герикович В.Ф. Солнечные установки горячего водоснабжения: пособие по проектированию. ЗНИИЭП. Киев. 2006. 26c.

\section{REFERENCES}

1. Kudrja S.O. Netradycijni ta vidnovljuvani dzherela energhiji. [Alternative and renewable energy sources]. Pidruchnyk. Nacionaljnyj tekhnichnyj universytet Ukrajiny («KPI»). Kyjiv. 2012. 495 p. [in Ukrainian].

2. Mkhitaryan N.M. Energetika netraditsionnykh vozobnovlyaemykh istochnikov. [Alternative and Renewable Energy]. Naukova dumka. Kiïv. 1999. 314 p. [in Russian].

3. Daffi U.Dzh., Bekman U.A. Teplovye protsessy s ispol'zovaniem solnechnoy energii. [Thermal processes using solar energy]. Pod red. Yu.N.Malevskogo. Moskva. 1977. 420 p. [in Russian].

4. Tvaydell Dzh., Ueyr A. Vozobnovlyaemye istochnik energii. [Renewable energy sources]. Energoatomizdat. Moskva. 1990. 344 p. [in Russian].

5. Nauchno-prikladnoy spravochnik po klimatu SSSR. Ser. Vyp. 10. USSR. Kn. 1. Ch. 1. Solnechnaya radiatsiya i solnechnoe siyanie. [Scientific-applied reference on the climate of the USSR. P.1 Solar radiation and solar luminescence]. Gidrometeoizdat. 1990. 608 p. [in Russian].

6. Rekomendatsii po proektirovaniyu ustanovok solnechnogo goryachego vodosnabzheniya dlya zhilykh i obshchestvennykh zdaniy. [Recommendations for the design of solar hot water installations for residential and public buildings]. KievZNIIEP. Kiev. 1987. 119 p. [in Russian].

7. Gershkovich V.F. Solnechnye ustanovki goryachego vodosnabzheniya: posobie po proektirovaniyu. [Solar Hot Water Plants: Design Guide]. ZNIIEP. Kiev. 2006. 26 p. [in Russian].

\section{ОПРЕДЕЛЕНИЕ ЭФФЕКТИВНОСТИ ВНЕДРЕНИЯ СИСТЕМ СОЛНЕЧНОГО ГОРЯЧЕГО ВОДОСНАБЖЕНИЯ}

C.В. Матях, канд. техн. наук, Т.В. Суржик, канд. техн. наук, В.Ф. Резцов, чл.-кор. НАН Украины, докт. техн. наук

Институт возобновляемой энергетики НАН Украины, 02094, ул. Гната Хоткевича 20A, г. Киев, Украина.

Использование современных солнечных коллекторов обеспечивает высокий уровень освоения энергии солнечного излучения и стабильность горячего водоснабжения в течение всего года на всей территории Украины. На современном этапе развития солнечной теплоэнергетики на первое место выходят проблемы эффективного использования энергии солнечной радиации за счет применения передовых технологий и установления оптимальных параметров энергетического оборудования.

Представленный в работе порядок определения эффективности использования систем солнечного горячего водоснабжения обеспечивает определение энергетических $и$ экономических параметров солнечного теплоэнергетического оборудования в конкретной местности, определение типа и параметров гелиоустановок для их максимально эффективного использования.

Выбор типа и производительности солнечных коллекторов для определенной местности в первую очередь ориентирован на потребности конкретного потребителя и удельные показатели поступления солнечной радиации в данной местности (среднемесячное и среднегодовое количество прямой, рассеянной и суммарной солнечной радиации). На основе представленных данных определяется приведенная суточная интенсивность поглощения солнечным коллектором солнечной радиации с учетом рабочих параметров гелиотехнической установки и оптимального угла наклона к горизонту. Расчетные энергетические параметры в дальнейшем используются для установления экономической эффективности, срока окупаемости гелиоустановки и экологической эффективности за счет уменьшения выбросов углекислого газа. Солнечное теплоснабжение в Украине имеет достаточный опыт использования и развитую нормативную базу для проектирования, а технологический потенциал промышленности позволяет решать задачи массового производства гелиотехнического оборудования. Предложенный порядок оперативного определения эффективности внедрения систем солнечного горячего водоснабжения для потенииальных потребителей будет способствовать широкому освоению солнечной тепловой энергии на всей территории Украины и, соответственно, уменьшению объемов использования органического топлива и улучшению состояния окружающей среды.Библ. 7, табл. 2.

Ключевые слова: солнечная теплоэнергетика, солнечный коллектор, горячее водоснабжение.

Стаття надійшла до редакції 16.01.20 Остаточна версія 19.03.20 